\title{
Geolektalne pułapki języka hiszpańskiego w praktyce przekładu pisemnego i ustnego
}

\section{Geolectal traps of the Spanish language in practice, written and oral translation}

\author{
Edyta Kwiatkowska Faryś \\ Agata Wolarska-Sobocińska \\ WYDZIAŁ NEOFILOLOGII, UNIWERSYTET IM. ADAMA MICKIEWICZA \\ AL. NIEPODLEGŁOŚCI 4, 61-874 POZNAŃ \\ kedytalamu.edu.pl \\ agata.wolarskaeamu.edu.pl
}

\begin{abstract}
In the translatological perspective, the pluricentricity and big number of standard varietes of the Spanish language is a challenge, especially at the semantic and lexical level, as well as the phonetics and pragmatics are concerned. This study is an attempt to present the complexity and multidimensionality of the problem. On the basis of selected specific examples, the paper shows how the ability to recognize and distinguish specific geolects equips a translator/interpreter of Spanish with the tools of effective communication and a culture oriented interpretation.
\end{abstract}

Przekład specjalistyczny - jako zjawisko i proces sam w sobie - stwarza dylematy związane z różnymi uwarunkowaniami języków i kultur.

Pozycja tłumacza języka hiszpańskiego jest szczególnie niekomfortowa, co jest spowodowane wielością standardowych wariantów regionalnych tego 
języka. Policentryczność języka hiszpańskiego wynika zarówno z ogromniej liczby jego użytkowników, jak i rozległości obszaru jego stosowania i znacznych odległości między poszczególnymi obszarami, gdzie kształtowały się geolekty, rozumiane jako warianty diatopiczne tego samego języka.

Według raportu Instytutu Cervantesa na świecie jest niemal pięćset milionów ${ }^{1}$ natywnych użytkowników języka hiszpańskiego (Fernandez Vitores, 2018: 6-8). Dziewięć dziesiątych z tej liczby to populacja krajów, gdzie hiszpański jest językiem urzędowym, są to użytkownicy dwudziestu jeden ustandaryzowanych wariantów geograficznych tego języka. Język hiszpański można bez wątpienia zaliczyć do języków policentrycznych, stwarzających wyzwanie w perspektywie translatologicznej, szczególnie na poziomie semantyczno-leksykalnym, a w przypadku przekładu ustnego także fonetyczno-fonologicznym i pragmatycznym. Niniejsze opracowanie stanowi próbę przedstawienia złożoności i wielopłaszczyznowości problemu. Prezentowane zagadnienia dotyczą zarówno przekładu ustnego jak i pisemnego, jednak przedstawiany materiał koncentruje się w głównej mierze na tłumaczeniach pisemnych.

\section{Hispanofonia}

Wspólnota języka hiszpańskiego rozciąga się na bardzo rozległym terytorium, obejmującym głównie: Półwysep Iberyjski, kraje obu Ameryk od Meksyku na północy aż po Argentynę na południu, a także Gwineę Równikową, Saharę Zachodnią, północnoafrykańskie miasta Ceuta i Melilla, azjatyckie Filipiny oraz, co nie bez znaczenia, liczne obszary USA².

\footnotetext{
${ }^{1} \mathrm{Wg}$ opracowanych na podstawie oficjalnych spisów danych przytaczanych przez raport Instytutu Cervantesa na grupę rodzimych użytkowników hiszpańskiego (łącznie z użytkownikami dwujęzycznymi) składa się 434.875.921 osób w krajach hiszpańskojęzycznych i 45.353.721 osób w krajach, gdzie język hiszpański nie ma statusu języka urzędowego (Fernandez Vitores, 2018: 10).

2 Warianty hiszpańszczyzny w krajach, gdzie język ten nie ma statusu języka urzędowego, są interesujące z punktu widzenia geografii lingwistycznej, niemniej nie wydają się istotne dla tłumaczenia specjalistycznego, głównie dlatego, że - co do zasady - nie będąc wariantami urzędowymi, nie generują tekstów mogących być przedmiotem takiego przekładu.
} 
Diatopięs języka hiszpańskiego przedstawia się najczęściej (Hualde i in., 2009: 438-439) w podziale na następujące strefy regionalne:

- hiszpański peninsularny, zwany w samej Hiszpanii kastylijskim (w celu odróżnienia od pozostałych oficjalnych języków Hiszpanii), stosowany na Półwyspie Iberyjskim, Balearach, Wyspach Kanaryjskich;

- hiszpańszczyzna Meksyku i Ameryki Środkowej (Gwatemala, Salwador, Honduras, Nikaragua, Kostaryka, Panama);

- hiszpański karaibski (Antyle, Wenezuela, atlantyckie wybrzeże Kolumbii);

- hiszpańszczyzna andyjska (Kolumbia, Peru, Boliwia, Ekwador, część Wenezueli i północno-zachodnia Argentyna);

- hiszpański rioplateński (Argentyna, Urugwaj, Paragwaj);

- hiszpański chilijski (Chile) ${ }^{4}$.

Jeśli prześledzić historię języka hiszpańskiego i stosunku badaczy tego języka do latynoamerykanizmów5, jaki prezentowali wielcy filolodzy hiszpańscy tacy jak Menéndez Pelayo, Américo Castro, a nawet latynoscy, tacy jak Andrés Bello, do niedawna pośród językoznawców, szczególnie dialektologów, panował pogląd, który dziś nazwalibyśmy kolonializmem językowym, przymusową „kastelianizacją” lub po prostu supremacją wariantu z Hiszpanii (i to tego jednego: kastylijskiego). Niemniej, od drugiej połowy XX wieku nie ma już wątpliwości, że język hiszpański to język o wielu standardowych odmianach ${ }^{6}$.

3 W rozumieniu ogólnym (Coseriu, 1981).

4 Powyższa klasyfikacja jest ogólna i daleka od doskonałości, jednakże dotychczasowe badania dowiodły, że podział wariantów hiszpańszczyzny ze względu na poszczególne kryteria (np. fonetyczne, morfologiczno-fonetyczne, składniowo-leksykalne) - metodologicznie właściwszy - bez jednoczesnego uwzględnienia ogółu podobieństw i zbieżności, albo wpływu współistniejących języków, nie obejmowałby całości zjawiska geolektalnej różnorodności języka hiszpańskiego. Zob. Pottier (1992: 283-295) i zawarte w tamże referencje.

5Hiszp. americanismos - termin oznaczający słowa właściwe hiszpańszczyźnie latynoamerykańskiej, zarówno pochodzące z języków indiańskich, jak i powstałe na gruncie amerykańskich wariantów języka hiszpańskiego (zob. Diccionario de la Real Academia Española [DRAE]: https://dle.rae.es/?id=2KBbsFD).

${ }^{6}$ Wskazują to także polscy badacze, np. Szałek, 2013. 


\section{Geolekty}

O tym, że żaden z geolektów nie jest mniej standardowy od pozostałych świadczy istnienie w krajach hispanofońskich odrębnych Akademii Języka Hiszpańskiego. Uznanie faktu, że standardy te podlegają stałemu regionalnemu różnicowaniu, rządzą się różnymi zasadami gramatycznymi, a także mają różne zasoby leksykalne wobrębie tego samego języka, odzwierciedliło powołanie w Meksyku w 1951 roku Stowarzyszenia Akademii Języka Hiszpańskiego [Asociación de Academias de la Lengua Española - ASALE]. ASALE zrzesza 22 organizacje zajmujące się normatywizacją i kodyfikacją języka hiszpańskiego w poszczególnych krajach, a jej statutowym celem jest „utrzymanie integralności i wspieranie dalszego wzrostu i rozwoju języka hiszpańskiego” (Statut ASALE art. 7).

Geolekty stanowią wzorce językowe na poszczególnych obszarach występowania i dotyczą wszystkich rejestrów języka (Alvar, 1996:6). Akademie języka poszczególnych krajów hiszpańskojęzycznych współpracują ze sobą, monitorując zachodzące procesy językowe i generując wspólne zasoby i słowniki. Dzięki postępującej globalizacji i dostępności zasobów coraz wyraźniej widać skalę regionalnej wariantywności języka hiszpańskiego.

Jak już powiedziano, z punktu widzenia lingwistycznego (polityki językowej) i społecznego (poprawności politycznej), w hispanofonii XXI wieku nie promuje się jednego obowiązującego standardus. W konsekwencji, współczesna wyraźna diatopia hiszpańszczyzny staje się czynnikiem, który może spowodować liczne dylematy wdziedzinie przekładu.

Ze względu na terytorialny zasięg języka hiszpańskiego regionalne odmiany języka (zwane geolektami lub wariantami diatopicznymi, czy też

\footnotetext{
7 Np. Diccionario de americanismos, Asociación de Academias de la Lengua Española, Santillana, Madryt 2010.

8 Por. sytuację j. portugalskiego, np. Wolarska A., Traktaty międzynarodowe vs. produkt, w: Norma a uzus II przekład specjalistyczny $w$ perspektywie globalizacji, Wydawnictwo Naukowe UAM 2017, Red.: Walkiewicz B., Kęsicka K., s. 159-168.
} 
wariantami horyzontalnymi) wykazują duże zróżnicowanie zarówno w języku potocznym jak i normie poprawnościowej. Piramida językowa wskazuje, że różnice w rejestrze mówionym są większe.

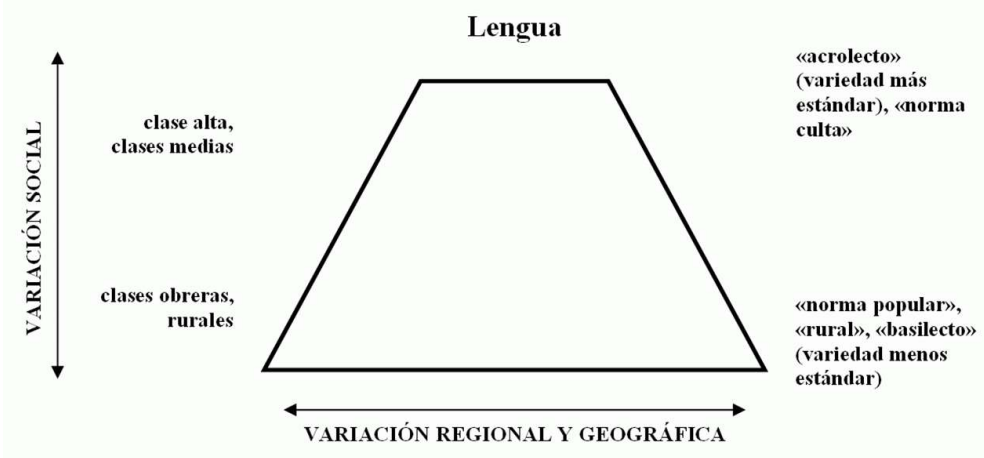

Rys. 1. Piramida języka wskazująca relacje diatopii, diastratu i diafazy języka hiszpańskiego (Ramírez, 1996: 37).

Jak możemy zaobserwować piramida przedstawia stosunek wariantów diatopicznych (wskaźnik poziomy) do wariantów diastratycznych, zróżnicowania społecznego (wskaźnik pionowy); górna część piramidy obrazuje wyższe warstwy społeczne (lewa strona) oraz normę językową (akrolekt), natomiast dolna część piramidy to niższe warstwy społeczne (np. robotnicza) oraz bazylekt.

\section{Wariantywność na poziomie podsystemów języka}

Gdy językiem posługuje się populacja na bardzo rozległym obszarze, ma on tendencję do widocznego różnicowania się ze względu na położenie geograficzne. Z kolei komunikując się w znanym języku, lecz w nowym kontekście geograficznym, stajemy przed koniecznością dostosowania się w różnym zakresie - do lokalnego wariantu. Oznacza to głównie zapoznanie się i stosowanie nowych zasobów semantyczno-leksykalnych lub znanych zasobów w nowym kontekście, uzusie.

W przypadku języka hiszpańskiego jego regionalne standardy wykazują różnice w zasadzie we wszystkich podsystemach języka oraz jego rejestrach: 
a) fonetyczno-fonologicznym (np. zjawisko seseo, yeísmo);

b) gramatycznym (np. zwiększone użycie zaimków dopełnieniowych, zamienne stosowanie zaimków dopełnienia bliższego i dalszego, niestosowanie drugiej osoby liczby mnogiej w paradygmacie czasownika, voseo, odmienne normy stosowania czasów gramatycznych);

c) leksykalnym (zob. liczne glosariusze i zestawienia, np. przytaczane w niniejszej pracy lub dostępne powszechnie w sieci).

Nie bez znaczenia jest także wpływ języków wernakularnych, języków grup emigranckich lub języków współoficjalnych, a także postępujące wraz z globalizacją, lecz odmienne w poszczególnych wariantach, stosowanie anglicyzmów.

W przypadku wariantów latynoamerykańskich można zaobserwować także występowanie swego rodzaju archaizmów9 leksykalno-semantycznych (cobija jako manta, carro jako coche, alberca jako piscina, aretes jako pendientes, ¿̇mande? jako ¿̇cómo?, merced jako usted).

Jednocześnie nie należy zapominać o różnicach w wariantach na poziomie emfazy oraz różnicach wynikających z odmiennej estetyki. Tu przykładem może być stosowanie deminutywów lub pragmatyka wypowiedzi i grzeczność językowa, jak ta na przykład, nakazująca Meksykanom odpowiadać całym zdaniem i udzielać odpowiedzi na zadane pytania, nawet gdy nie mają stosownej wiedzy. Stanowi to problem głównie w przekładzie ustnym (np. ¿Qué hora es? Pues mire, no sabría decirle, creo que serían las tres o antes).

Rozpoznanie konkretnych geolektów języka hiszpańskiego oraz umiejętność ich rozróżnienia wyposażają tłumacza w narzędzia skutecznej komunikacji oraz właściwej interpretacji wrażliwości językowej i kulturowej nadawcy/odbiorcy.

9 Chodzi o taki zasób, który jest postrzegany jako dawny w wariancie europejskim. 


\section{Material i metoda}

Materiał badawczy niniejszej pracy został uzyskany z obserwacji własnej oraz translatorskiej praktyki autorek. Za źródła oraz referencje posłużyły również: Corpus de Referencia del Español Actual (CREA) RAE ${ }^{10}$ oraz słowniki amerykanizmów Diccionario de americanismos (2010), Diccionario del habla de los argentinos (2003), Nuevo diccionario de americanismos. Tomo I, Tomo II (1993), Diccionario del español usual en México (2002), Nuevo diccionario de costarriqueñismos (2007).

Wybrane pułapki translatorskie pojawiały się $\mathrm{w}$ przekładach z języka hiszpańskiego na język polski i związane są głównie $\mathrm{z}$ właściwym rozpoznaniem geolektu. Dodatkowo wskazujemy także przypadki przekładu na język hiszpański, gdzie oprócz właściwego rozpoznania geolektu odbiorcy, zasadniczym dylematem tłumacza staje się wybór między podjęciem arbitralnej decyzji o zastosowaniu któregoś wariantu (niekoniecznie tłumacz zna je wszystkie, nie zawsze wie, kim jest odbiorca), stosowaniem znanego sobie geolektu, a próbą wygenerowania tak zwanego wariantu neutralnego (wymaga to odpowiedniej świadomości różnic na poziomie podsystemów języka i pragmatyki oraz licznych kontekstów kulturowych).

W badanym obszarze rozstrzygania problemów różnych odmian hiszpańszczyzny warto skorzystać z perspektywy, jaką daje lingwistyka kulturowa. Polska szkoła etnolingwistyczna (Anusiewicz, 1994) wskazuje na rolę języka w kształtowaniu obrazu otaczającej nas rzeczywistości i w sposobie jej wyrażania, a w konsekwencji podkreśla wielość konceptualizacji poszczególnych pojęćc ${ }^{11}$. Stąd za kluczową uważamy szczególną wrażliwość tłumacza języka hiszpańskiego na zróżnicowanie geolektalne i dostosowanie się do właściwego wariantu lub „neutralizację”

\footnotetext{
${ }^{10}$ Autorki korzystały również z Corpus del Español del Siglo XXI (CORPES, wersja o.9) RAE, jednak ze względu na jej testowy charakter nie pojawia się ona w niniejszym opracowaniu.

${ }^{11}$ Zob. też Palmer, 1996.
} 
wariantu, który dla nadawcy/odbiorcy tłumaczonego tekstu może być kulturowo nieprzyjazny.

\section{Pozycja tłumacza wobec hiszpańskiego jako języka policentrycznego}

Liczne glosariusze i słowniki (zob. bibliografia) dostarczają zasobów świadczących o policentryczności hiszpańszczyzny na poziomie języka potocznego. Naturalnie, dla tłumacza tekstów specjalistycznych najistotniejsza pozostaje uważność na zróżnicowanie języka na poziomie norm poprawnościowych oraz wspomnianej emfazy i wrażliwości językowej.

Pierwszy z dylematów pojawia się w zasadzie wraz z samym terminem określającym język. W zależności od estetyki konkretnego wariantu, termin español lub castellano - na określenie języka hiszpańskiego - stosuje się wymienne w niektórych krajach (Kolumbia, Wenezuela), w innych zaś tylko español (Meksyk, kraje Ameryki Centralnej) lub tylko castellano (Argentyna, Urugwaj, Chile). Kwestia ta zależy od utrwalonego uzusu, niejednokrotnie zbudowanego już w XIX na opozycji do kraju-metropolii. W Hiszpanii z kolei termin castellano, zgodnie z normą poprawnościową Real Academia Española (RAE) (zob. Diccionario de la Lengua Española DLE, 2017) powinien być używany tylko, gdy stoi w opozycji do pozostałych języków urzędowych ${ }^{12}$.

\subsection{Pułapki leksykalno-semantyczne}

Przede wszystkim, w pierwszym kontakcie regionalne zróżnicowanie języka hiszpańskiego wprowadza nas w pułapki leksykalno-semantyczne. Liczne ich zestawienia można poznać w rozmaitych glosariuszach. Powszechnie znane pary diatopiczne to durazno/melocotón, manejar/conducir, botar/echar, col/repollo, arvejas/guisantes, chavo/pibe. Synonimy, wśród

12 Zgodnie z konstytucją z 1978 r. są nimi: galisyjski, baskijski i kataloński. 
których niektóre mogą być w innych geolektach odbierane jako archaizmy, to na przykład acera/banqueta/vereda, pileta/alberca/piscina, czy też redondel/rotonda/glorieta.

Poniżej kilka wybranych przykładów pułapek leksykalno-semantycznych.

a. Pary synonimiczne a przesunięcia semantyczne

Tam, gdzie mamy do czynienia z synonimami, różniącymi się regionalnie frekwencją użycia, tłumacz nie napotyka większych problemów warsztatowych. Na przykład meksykańskie platicar i ogólnohiszpańskie conversar mogą być przełożone polskim czasownikiem rozmawiać. Jednak już w przypadku pary brindar/dar (dawać), tłumacz musi wiedzieć, że w geolekcie europejskim pierwszy z tych czasowników od dawna nie ma zastosowania w tym znaczeniu (i zasadniczo oznacza wznosić toast). W parze synonimów recto/derecho hiszpański przymiotnik recto (prosty, równy) występuje w funkcji przysłówka „prosto” (sigue recto) wyłącznie w Hiszpanii, i trudno oczekiwać, by użyto go w tej funkcji w Latynoameryce, gdzie w zastosowaniu jest derecho (sigue derecho).

Klasyczny już przykład pary tomar/coger pomijamy, jako powszechnie znane tabu językowe.

Innych oczywistych par przytoczyć można wiele, np: dormitorio/recámara, apartamento/departamento, sala/salón, alquilar/rentar, elevador/ascensor, estacionamiento/aparcamiento. Pamiętający o regionalnym charakterze tych określeń tłumacz i tak stanie przed dylematem, gdy przyjdzie mu pracować nad przekładem na język hiszpański materiałów mających służyć tak zwanemu szerokiemu odbiorcy. Jako przykład z praktyki własnej możemy podać pracę nad hiszpańskojęzycznym audioprzewodnikiem po polskich zabytkach kultury²3. Ponieważ trudno o „neutralizację” (pozbawienie cech regionalnych), w sytuacji, gdy każdy z synonimów jest nacechowany regionalnie, tłumacz

13 Przekład na hiszpański audioprzewodników po Zamku Królewskim w Warszawie i Łazienkach Królewskich (tłum. E. Kwiatkowska-Faryś, 2017). 
musi opowiedzieć się po stronie któregoś z geolektów lub tzw. wariantów globalnych (o czym w dalszej części artykułu).

b. Różnice terminologiczne

Z punktu widzenia tłumacza specjalistycznego różnice terminologiczne stanowią najciekawszą kategorię: wykształcone na przestrzeni ostatnich dwustu lat odrębne systemy administracyjne i prawne mają bowiem swoje odzwierciedlenie wterminologii.

I tak, na przykład, o ile terminy licencia de conducción, carné o permiso de conducción (Hiszpania), licencia de conducir (Argentyna); permiso de conducir (Meksyk) lub licencia de manejo (np. Kolumbia) odpowiadające temu samemu konceptowi dokumentu upoważniającego do prowadzenia pojazdu - brzmią podobnie i mają identyczną strukturę ${ }^{14}$, to już nie jest tak w przypadku libreta de enrolamiento (Argentyna), cedula de identidad (Chile, Urugwaj, Wenezuela), cédula de ciudadania (Kolumbia), documento nacional de identidad (Hiszpania), carné electoral (Salwador), cedula de vecindad (Gwatemala), credencial de elector (Meksyk), libreta electoral (Peru). Tłumacz powinien umieć odnieść ten termin do konceptu dokumentu tożsamości i zastosować właściwie w zależności od kierunku tłumaczenia i regionalnego standardu odbiorcy ${ }^{15}$.

Rioplateńskie escribano to notariusz (notario) i poza administracją argentyńską, urugwajską i paragwajską termin ten jest niezrozumiały w aktualnym znaczeniu. Niemniej escritura to termin określający akt notarialny stosowany już we wszystkich wariantach języka hiszpańskiego, jak także acta notarial.

I jeszcze jeden przykład, tym razem pochodzący z języka mediów, który odnosząc się do spraw poszczególnych regionów chętnie czerpie ze specyfiki miejscowych wariantów języka hiszpańskiego. Globalny dziennik hiszpańskojęzyczny El País, mający tak zwane wydanie światowe, gdy pisze

\footnotetext{
14 Podobieństwo nie jest już tak oczywiste w przypadku peruwiańskiego terminu brevete. 15 O czym także u: A. Wolarska, Różnice kulturowe w aspekcie tłumaczenia specjalistycznego, wykład plenarny Konferencja PT TEPiS Przekład Prawniczy i Specjalistyczny, 8-9.10.2016.
} 
o korupcji w Argentynie użyje terminu coima, w Meksyku pago, w Hiszpanii soborno, a wszystko to oznaczać będzie cohecho czyli łapówkę. Naturalnie regionalizmy mogą pozostać niezrozumiałe, co dokumentuje użycie odredakcyjnego synonimu $\mathrm{w}$ tekście, stanowiące właściwie przykład tłumaczenia wewnątrzjęzykowego: „Tradicionalmente los pagos (sobornos) han salido de Los Pinos a las grandes cadenas" ${ }^{16}$.

c. Osobliwości semantyczne

$\mathrm{Z}$ praktyki tłumaczenia $\mathrm{w}$ obie strony pochodzi dylemat dotyczący przekładu toponimu „rynek główny / rynek Starego Miasta”. Plaza mayor będzie zrozumiałe tylko w Hiszpanii, dla Andyjczyka to plaza de armas, dla Meksykanina zócalo, dla Panamczyka parque. Jeśli tłumacz właśnie przekłada na hiszpański przewodnik po polskim mieście, staje przed nie lada problemem. Czy ekwiwalent, czy tłumaczenie opisowe będzie tu miało zastosowanie? Z kolei w drugą stronę, o ile w przekładzie literackim można zaakceptować Plac Broni17, to jednak dosłowność w przypadku zócalo (cokół), parque (park) czy plaza mayor (główny plac) jest w tym wypadku oczywistym absurdem w przekładzie użytkowym.

\section{d. Adresatywy i tytulatura}

W przekładzie na język hiszpański należy uważać na adresatywy, w stosunku do których postulujemy jak najdalej idącą neutralizację, czyli pozbawienie cech regionalnych. W standardach językowych poszczególnych krajów stosowanie powszechnie zrozumiałych adresatywów, takich jak don, doña, señor, señora, señorita, licenciado, oficial, merced, usted, jest zasadniczo odmienne i mocno osadzone w miejscowym uzusie. Dlatego na przykład należy pamiętać, że anachroniczne dla większości merced do dziś jest w użyciu w niektórych rejonach Kolumbii, meksykańskie don i doña

16 Zob. J. García, "Meade es un anticlímax” Entrevista a Epigmenio Ibarra, productor mexicano, El País Internacional, 5.01.2018:

https://elpais.com/internacional/2018/01/03/mexico/1515020109 947798.html.

$17 \mathrm{~Np}$. w polskim przekładzie Vargasa Llosy tłumacz, zakładając odpowiednie przygotowanie kulturowe czytelnika polskiego, tak właśnie przełoży plaza de armas. 
odnoszą się już aktualnie wyłącznie do domowego personelu pomocniczego, a $\mathrm{z}$ kolei mocno nacechowana $\mathrm{w}$ Hiszpanii señorita $\mathrm{w}$ wariancie meksykańskim jest wyrazem szacunku i stosuje się ten adresatyw przy zwracaniu do nawet bardzo dojrzałych kobiet. Pomijamy tutaj zwroty familiarne, których zasób i stosowanie są zdecydowanie różne w poszczególnych geolektach, ale ich zróżnicowanie jest mniej istotne zpunktu widzenia przekładu specjalistycznego.

\section{e. Zwroty i frazy idiomatyczne}

$\mathrm{Na}$ liczne pułapki idiomatyczne narażony jest tłumacz $\mathrm{w}$ sytuacji przekładu środowiskowego. Zwrot oznaczający dosłownie „co pan każe” ¿mande? jest w Meksyku najgrzeczniejszym wariantem zwrotu odpowiadającego polskiemu „słucham?”. W pozostałych wariantach hiszpańskiego nie występuje, a ich użytkownikom wydaje się zaskakującym anachronizmem.

Odpowiadająca podziękowaniom hiszpańska fraza „no hay de que” (nie ma za co), w uzusie rioplateńskim zwykle sprowadza się do eliptycznej formy „no” (nie), a w uzusie północno i środkowoamerykańskim do „de que” (za co), co bez świadomości kontekstu mogłoby zostać mylnie przetłumaczone. W europejskim standardzie stosuje się z większą częstotliwością synonimiczne wyrażenie „de nada” (za nic), wystarczająco krótkie, by nie ulegać brutalnej ekonomice wypowiedzi.

\subsection{Różnice gramatyczne}

W przypadku różnic morfosyntaktycznych między geolektami mamy do czynienia ze znaczną odmiennością nie tylko między wariantem europejskim, a geolektami latynoamerykańskimi, ale także można zaobserwować zasadnicze różnice między standardami amerykańskimi.

a. Największy problem dla niewyrobionego tłumacza stanowi zjawisko voseo. O ile w Kolumbii i Ameryce Środkowej stosowanie vos w miejsce tú, wraz z wynikającymi z tego zmianami paradygmatu 
czasowników, jest cechą rejestru potocznego, w krajach Cono Sur voseo stanowi standard poprawnościowy we wszystkich rejestrach argentyńskiej, urugwajskiej i paragwajskiej hiszpańszczyzny i nie da się go „zneutralizować” czyli pozbawić cech regionalnych w celu umożliwienia szerszego zrozumienia.

b. Stosowanie form czasu przeszłego rządzi się dużo bardziej liberalnymi regułami w krajach Ameryki niż w Hiszpanii, a czasowniki perfektywne coraz rzadziej występują w rejestrze potocznym. Stąd zastosowanie Pretérito Indefinido (hoy fui) w miejsce Pretérito Perfecto (hoy he ido) nie będzie postrzegane w tych wariantach jako usterka gramatyczna w przekładzie ${ }^{18}$.

c. Dla wariantu meksykańskiego charakterystyczne jest stosowanie deminutywów i augmentatywów. Głównie są to zdrobnienia afektywne, takie jak tuyito, ratito, ahorita, tempranito. Niejednokrotnie jednak leksykalizują się one i, zwłaszcza w przypadku przysłówków, nabierają nowego znaczenia: ahorita to już nie „teraz”, lecz „wkrótce” (en breve); al ratito (más al ratito) to już nie „za chwilę” lecz „za jakiś czas (trochę później)”19.

\subsection{Wlaściwy rejestr i emocjonalny poziom wypowiedzi}

Niestety, co już w pewnej mierze wskazano, uważność geolektalna tłumacza języka hiszpańskiego nie dotyczy wyłącznie znajomości różnic leksykalnych i gramatycznych. Odmienna stylistyka i zróżnicowane normy poprawnościowe utrudniają tłumaczowi rozpoznanie właściwego rejestru i emfatycznego poziomu wypowiedzi.

${ }^{18} \mathrm{Z}$ kolei gramatyczny czas Preterito Perfecto w Amerykach występuje w uzusie pragmatycznym specjalnego użycia peninsularnego.

19 Odpowiada to przysłówkom más tarde oraz un poco más tarde $\mathrm{w}$ pozostałych wariantach. 
W przypadku przekładu ustnego, prócz sprawności językowej, grzeczność językowa, intonacja i mowa ciała mają niebagatelne znaczenie. Przykładowo, hiszpański ton wypowiedzi jest nie do przyjęcia w Meksyku, a argentyńska poufałość i natychmiastowe przechodzenie w rozmowie na ty (nawet $\mathrm{w}$ rozmowach oficjalnych) szokuje $\mathrm{w}$ dyskursie oficjalnym w Kolumbii. Z kolei występowanie wyrazów nacechowanych emocjonalnie, zwłaszcza potocyzmów, ułatwia tłumaczowi rozpoznanie właściwego wariantu języka hiszpańskiego ${ }^{20}$.

\section{Hiszpański wariant neutralny (globalny)}

Wobec wielości wariantów normatywnego standardowego hiszpańskiego i wynikających z tego trudności dla tłumacza tego języka, w przekładzie specjalistycznym, a zwłaszcza w przekładzie związanym z nowymi technologiami, w mediach, w przemyśle kultury oraz w przemyśle rozrywkowym, od półwiecza mamy do czynienia z próbami uniwersalizacji hiszpańskiego. Tak zwany wariant neutralny (neutro) miałby być sposobem na zaradzenie rozbieżnościom geolektalnym. Rozbieżności, które rejestruje panhiszpański słownik poprawnej hiszpańszczyzny, Diccionario panhispánico de dudas z roku 2005, są dzięki pracy leksykologów oraz postępującej globalizacji w przepływie informacji, coraz bardziej rozpoznawane i przyswajane. Nie wynika z nich niestety, bo też nie może, żadna powrotna uniformizacja języka (nawet na poziomie normatywnym).

Stąd pomysł na stworzenie wariantu neutralnego (zob. Llorente Pinto, 2006) niwelującego najbardziej niewygodne dla odbiorcy różnice regionalne. Neutralizacja hiszpańszczyzny rozpoczęła się dzięki przemysłowi kultury, a szczególnie dzięki listom dialogowym filmów przekładanych z języków obcych oraz producentom telenowel. Obecnie

\footnotetext{
${ }^{20}$ Oczywiste odniesienie regionalne będzie mieć miejsce, rzecz lub wydarzenie, które jest bacán (Peru), chévere (Panama, Kolumbia), bárbaro (Cono Sur), padre (Meksyk, USA), czyli wzbudzające bardzo pozytywne emocje i dostarczające wrażeń. Uważny tłumacz powinien naturalnie rozpoznać znaczenie figuratywne takich określeń, co nie zawsze ma miejsce: np. zdarzają się pomyłki typu ,jest bardzo ojcem" (es muy padre).
} 
właściwie powinniśmy mówić o przynajmniej trzech tak zwanych wariantach neutralnych.

Warianty neutralne tworzone są dla rozległych terytoriów obejmujących różne geolekty, a formuje się je poprzez wybór i zastosowanie najpowszechniejszych na tych obszarach form leksykalno-semantycznych i gramatycznych. Obserwując tendencje współczesnego przemysłu medialnego można wyróżnić ich najistotniejsze cechy:

a) w miarę możliwości unikają terminów jednoznacznie kojarzonych z konkretną lokalizacją (takich jak np. móvil, ordenador - stosowane tylko w Hiszpanii);

b) w zakresie neutralizacji morfo syntaktycznej unikają charakterystycznego dla Cono Sur zjawiska voseo;

c) na podstawie korpusów oraz glosariuszy wybierają słownictwo o największej frekwencji (zob. przypadek arquero/portero w futbolu);

d) dążą do wypracowanie takich modeli wymowy, które nie kojarzą się jednoznacznie z konkretnym wariantem geograficznym: unika się więc odpowiednio seseo lub ceceo, karaibsko-andaluzyjskiego aspirowania fonemu /s/, czy też charakterystycznego zjawiska yeismo.

Zneutralizowane warianty są kolejnymi, ale nieumiejscowionymi, odmianami hiszpańszczyzny. Ze względu na znaczne zróżnicowanie geolektalne istnienie jednego globalnego wariantu neutralnego nie jest możliwe. Medioznawcy (np. Ávila, 2006, Petrella, 1998)²1 i językoznawcy z różnych krajów hiszpańskojęzycznych (Figueroa Saavedra, 2015, Garrido, 2010) wskazują na przynajmniej trzy: europejski (Hiszpania), rioplateński (Argentyna, Urugwaj, Paragwaj) i latynoamerykański (oparty na geolekcie meksykańskim wariant wspólny dla użytkowników hiszpańskiego w Meksyku, USA, Ameryce Centralnej i pozostałych krajach Ameryki Południowej).

${ }^{21}$ Zob. także opinie zamieszczone w: Cortés Bargalló Luis, Carlos Mapes, Carlos García Tort, 1998, La lengua española y los medios de comunicación, Siglo XXI, Meksyk - szczególnie II tom publikacji, poświęcony językowi telewizji. 


\section{Investigationes Linguisticae, vol. XXXIX}

Dużą zaletą idei wariantu neutralnego jest popularyzacja standardów językowych. Warianty neutralne paradoksalnie przyczyniają się także do rozpowszechnienia i zwiększenia rozpoznawalności najbardziej charakterystycznych regionalizmów. Warto jednak pamiętać, że pomocnicza, choć upraszczająca neutralizacja geolektów języka hiszpańskiego nie zwalnia tłumacza z uważności istałego treningu językowo-kulturowego. 
Edyta Kwiatkowska Faryś, Agata Wolarska-Sobocińska: Geolektalne

pułapki języka hiszpańskiego $w$ praktyce przekładu pisemnego i ustnego

\section{Bibliografia}

Academia Argentina de Letras, 2003, Diccionario del habla de los argentinos, Espasa Buenos Aires.

Asociación de Academias de la Lengua Española (ASALE), 2010, Diccionario de americanismos, Santillana, Madryt.

Alvar, M., red., 1996, Manual de dialectología hispánica: el español de América, Ariel, Barcelona.

Anusiewicz, J., 1995, Lingwistyka kulturowa. Zarys problematyki, Wydawnictwo UWr, Wrocław.

Ávila, A., 2006, De la imprenta a la Internet. La lengua española y los medios de comunicación masiva, El Colegio de México, Meksyk.

Baker, M., 1998, The Routledge Encyclopedia of Translation Studies, Londyn.

Biel, Ł., 2014, Lost in the Eurofog: The textual fit of translated texts, Frankfurt.

Cortés Bargalló, L., Mapes, C., García Tort, C. (red.), 1998, La lengua española y los medios de comunicación, Siglo XXI, Meksyk.

Coseriu, E., 1981, Lecciones de lingüística general, Gredos, Madryt.

Dąmbska-Prokop, U., 2000, Mała Encyklopedia Przekładoznawstwa, Częstochowa.

Fernández Vitores, D., 2018, El español: una lengua viva, Informe 2018, Instituto

Cervantes, Edición digital:

https://cvc.cervantes.es/lengua/espanol_lengua_viva/pdf/espanol_lengua_vi va_2018.pdf.

Figueroa Saavedra, M. 2015, Lengua española, contacto lingüístico y globalización, w: R. Terborg, A. Alarcón y L. Neri (red.), Lengua española, contacto lingüístico y globalización, UNAM, Meksyk, str. 57-93.

Garrido, J., 2010, Lengua y globalización: inglés global y español pluricéntrico, Historia y Comunicación social, 15, str. 67-102.

Giménez Folqués, D., 2010, "La lexicografía del español de América. Parte segunda. Repertorio de diccionarios”, w: M. Aleza Izquierdo y J. M. Enguita (red), La lengua española en América: Normas y usos actuales, str. 355-373, http://www.uv.es/aleza/esp. am.pdf

Grucza, F., 1985, „Lingwistyka, lingwistyka stosowana, glottodydaktyka, translatoryka", str. 19-44, w: Lingwistyka, glottodydaktyka, translatoryka, F. Grucza (red.), Warszawa.

Grucza, F., 2002, „Języki specjalistyczne - indykatory i/lub determinanty rozwoju cywilizacyjnego", w: Języki specjalistyczne. Problemy technolingwistyki, J. Lukszyn (red.), Warszawa.

Grucza, S., 2013, Lingwistyka języków specjalistycznych, Warszawa.

Gruszczyńska, E., 2014, „Norma językowa a przekład”, str. 10-21 w: Poradnik Językowy, nr 10 (719).

Haensch, G. i Werner, R. (red), 1993, Nuevo diccionario de americanismos. Tomo I. Nuevo diccionario de colombianismos, Instituto Caro y Cuervo, Bogota. 
Haensch, G. i Werner, R. (red.), 1993, Nuevo diccionario de americanismos. Tomo II. Nuevo diccionario de argentinismos, Instituto Caro y Cuervo, Bogota.

Hualde, J. I., Olarrea, A., Escobar, A. Ma , Travis, C. E., 2009, Introducción a la lingüística hispánica, Cambridge, str. 391-444.

Lara, L. F. i Anguiano Peña, G. (red.), 2002, Diccionario del español usual en México, El Colegio de México, Meksyk.

Llorente Pinto M., 2006, “Que es el español neutro”, Cuadernos del Lazarillo: Revista literaria y cultural, 31, str. 77-81.

López Morales, H., 2010, La andadura del español por el mundo, Taurus, Madryt. Moreno Cabrera, J. C., 2008, El nacionalismo lingüístico. Una ideología destructiva, Ediciones Península, Barcelona.

Palmer Gary, 1996, Toward a Theory of Cultural Linguistics, University of Texas, Austin.

Petrella, L., 1998, "El español «neutro» de los doblajes: intenciones y realidades", w: La lengua española y los medios de comunicación, t. II, red. Cortés Bargalló, L., Mapes, C., García Tort, C., Siglo XXI, Meksyk, str. 977-989..

Pottier, B., 1992, "La variación lingüística y el español de América", Revista de Fỉlología Española, vol. 72 (n. 3-4), str. 283-295.

Quesada Pacheco, M. Á., 2007, Nuevo diccionario de costarriqueñismos (wyd. 4)., Editorial Tecnológica de Costa Rica, Cartago.

Real Academia Española (RAE), 2005, Diccionario panhispánico de dudas (DPD), RAE, Madrid.

Real Academia Española (RAE), 2017, Diccionario de la lengua española (DLE), Edición de Tricentenario, actualización diciembre 2017 (versión electrónica 23.1.): http://dle.rae.es

Ramirez Arnulfo G., 1996, "Dialectología y sociolingüística", en Manual de dialectología hispánica: el español de España, ed. De Manuel Alvar, Ariel, Barcelona, str. 37-48.

Szałek, J., 2013, Neologia we współczesnym języku hiszpańskim, Scripta Neophilologica Posnaniensianr 13, str. 117-127.

Ziemska, J., 2003, Interkulturowe aspekty $w$ thumaczeniach tekstów fachowych $i$ $w$ nauczeniu języków specjalistycznych, [w:] P. Mamet, A. Mrózek (red.), Języki specjalistyczne. Zagadnienia dydaktyki i przekładu, Katowice. 